\title{
Nursing care systematization: perceptions and knowledge of the Brazilian nursing
}

\author{
Sistematização da assistência de enfermagem: percepção e conhecimento da enfermagem Brasileira \\ Sistematización de la asistencia a la enfermería: percepción y conocimiento de la enfermería Brasileña
}

Marcos Renato de Oliveira'
ORCID: 0000-0003-1803-9870
Paulo César de Almeida"
ORCID: 0000-0002-2867-802X

Thereza Maria Magalhães Moreira" ORCID: 0000-0003-1424-0649

Raimundo Augusto Martins Torres" ORCID:0000-0002-8114-4190

'Universidade Federal do Piauí. Picos, Piauí, Brazil. "Universidade Estadual do Ceará. Fortaleza, Ceará, Brazil.

How to cite this article: Oliveira MR, Almeida PC, Moreira TMM, Torres RAM. Nursing care systematization: perceptions and knowledge of the Brazilian nursing. Rev Bras Enferm. 2019;72(6):1547-53. doi: http://dx.doi.org/10.1590/0034-7167-2018-0606

Corresponding Author:

Marcos Renato de Oliveira

E-mail: enfmarcosrenato@hotmail.com

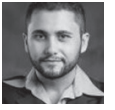

Submission: 07-20-2018 Approval: 01-26-2019

\begin{abstract}
Objective: to present the perception and knowledge of Brazilian nursing nurses and academics regarding Nursing Care Systematization. Method: a descriptive study, carried out in the first half of 2018. Results: of the 596 respondents, $86 \%$ perceived Nursing Care Systematization as very important, but only $60.9 \%$ used it in their care practice. Its use was statistically associated with a higher level of training. Non-utilization was associated with the perception that it is irrelevant and with little knowledge on the Nursing Process, even in the face of recognition of its obligation. Among professionals who wish to learn more about the subject, understanding the application of the process, especially the planning step, is perceived as a necessity. Conclusion: the relevance perception of systematization and levels of knowledge of the professional/academic are directly related to the use or not of Nursing Care Systematization principles. Descriptors: Nursing; Nursing Services; Nursing Process; Knowledge; Attitude.
\end{abstract}

\section{RESUMO}

Objetivo: apresentar a percepção e o conhecimento de enfermeiros e acadêmicos de enfermagem brasileiros quanto à Sistematização da Assistência de Enfermagem. Método: estudo descritivo, realizado no primeiro semestre de 2018. Resultados: dos 596 pesquisados, $86 \%$ perceberam a Sistematização da Assistência de Enfermagem como muito importante, mas somente $60,9 \%$ a utilizaram em sua prática assistencial. A utilização teve associação estatística com maior nível de formação. Já a não utilização, com a percepção de que esta é irrelevante e com baixo conhecimento sobre o Processo de Enfermagem, mesmo diante do reconhecimento de sua obrigatoriedade. Entre os profissionais que desejam aprender mais sobre o tema, compreender a aplicação do processo, em especial da etapa do planejamento, é percebido como necessidade. Conclusão: a percepção da relevância da sistematização e o nível de conhecimento do profissional/acadêmico são diretamente relacionados com o uso ou não dos princípios da Sistematização da Assistência de Enfermagem.

Descritores: Enfermagem; Serviços de Enfermagem; Processo de Enfermagem; Conhecimento; Atitude.

\section{RESUMEN}

Objetivo: presentar la percepción y el conocimiento de enfermeros y académicos de enfermería brasileños en cuanto a la Sistematización de la Asistencia a la Enfermería. Método: estudio descriptivo, realizado en el primer semestre de 2018. Resultados: de los 596 encuestados, $86 \%$ percibieron la sistematización de la asistencia de enfermería como muy importante, pero solamente el $60,9 \%$ la utilizaron en su práctica asistencial. La utilización tuvo asociación estadística con mayor nivel de formación. La no utilización, con la percepción de que ésta es irrelevante y con bajo conocimiento sobre el Proceso de Enfermería, aun ante el reconocimiento de su obligatoriedad. Entre los profesionales que desean aprender más sobre el tema, comprender la aplicación del proceso, en especial de la etapa de la planificación, es percibido como necesidad. Conclusión: la percepción de la relevancia de la sistematización y el nivel de conocimiento del profesional/académico son directamente relacionados con el uso o no de los principios de la Sistematización de la Asistencia a la Enfermería.

Descriptores: Enfermería, Servicios de Enfermería; Proceso de Enfermería; Conocimiento; Actitud. 


\section{INTRODUCTION}

Nursing work organization depends on a framework of knowledge and practices to be adequately selected by nurses in order to provide a safe nursing care focused on the needs of clients, being the care process systematization an essential technology to direct the actions of the team.

Nursing Care Systematization (NCS) is understood as any content/action that organizes the professional work of the nurse, with a theoretical-philosophical basis, that allows the operationalization of the Nursing Process (NP), with theoreticalphilosophical basis ${ }^{(1-2)}$.

NCS use is crucial to the provision of a safe nursing care, as it provides nurses with technical, scientific and human resources, improves the quality of care provided to the client and enables the recognition and appreciation of nursing in society ${ }^{(3-6)}$. Thus, in addition to collaborating for a safe nursing care, NCS and NP integration, once implemented and performed properly, collaborate to carry out academic research, legal analysis, auditing of accounts and general analysis of levels of quality of care of nursing ${ }^{(7)}$.

NCS can favor nurses' critical thinking and acting, as well as communication among all the nursing staff and the other members involved in the care ${ }^{(8)}$. However, despite the fact that NCS use is a legal requirement, as directed by the Brazilian Federal Nursing Council (Conselho Federal de Enfermagem) ${ }^{(1)}$, there is still discussion about its effectiveness and conflicts between nursing assistants and researchers regarding its application.

One of the problems around NCS is that, although it has regulations and publications that support it, it is still common the report by nurses about difficulties in the application of NCS in the daily practice of care, as well as perceiving it as a means to optimize clinical nursing care. Many academics, and even professionals with many years of experience, still confuse and/or summarize NCS as a mere tool of data collection, not understanding that it goes far beyond a bureaucratic activity. Still others associate it with simple forms and one more registration activity, among many performed by nurses.

Authors ${ }^{(9)}$ have pointed out for more than a decade that it is common for NP, care methodology and NCS itself to present themselves as synonyms and sometimes as different definitions. It is possible to perceive the misuse of these terms, generating conflict and difficulty of understanding about the professional practice of nursing, being this conflict still present in the current setting.

In many countries, as well as in the vast majority of Brazilian states, health institutions and their professionals have not yet complied with the full or even partial NCS implementation, amid a discourse of difficulties arising from its implementation and implementation. Among them, the lack of interest of the professional, the lack of knowledge, the lack of effective and the difficulty of acceptance of the multiprofessional team, due to the disbelief and rejection to the organizational changes $s^{(10-12)}$. Not infrequently, nurses actions are disconnected from NCS and implementation of NP, making the routine nursing routine; and the worst and most worrying, without sufficient scientific support ${ }^{(2)}$.

Based on these premises, technical-scientific preparation of professionals, favorable institutional conditions and involvement of the entire nursing team are indispensable for implementation and maintenance of $\mathrm{NCS}^{(11)}$, and it is also necessary to understand how the Brazilian nursing perceives NCS and NP. Thus, although there are publications with actions isolated from the implementation of NCS and NP, studies on variables related to practices that facilitate/hinder the systematized action of nursing are still necessary in order to better understand all this phenomenon ${ }^{(13)}$. This study was carried out in order to better understand these variables in the Brazilian community.

\section{OBJECTIVE}

To describe the perception and level of knowledge of Brazilian nurses and nursing academics regarding NCS.

\section{METHOD}

\section{Ethical aspects}

This research was approved after evaluation and positive opinion of the Research Ethics Committee of the Universidade Estadual do Ceará.

\section{Design, place of study and period}

This is a descriptive study, whose data were collected with nurses and nursing academics from Brazil through an electronic form after an invitation sent by e-mail to State Health Offices and Higher Education institutions in each state of the country, followed by the presentation of the study and referral to the target population. Completion of the online form at national level was accomplished in the first half of 2018.

\section{Population and sample; inclusion and exclusion criteria}

Population was composed of nurses and academics. In order to determine the total sample size, the following parameters were used: $95 \%$ confidence level ( $\mathrm{Za}$ ), sensitivity (Se) of the most important indicators of $80 \%$, half of the length of confidence intervals constructed of $5 \%(\mathrm{~L})$ and proportion of $97 \%$ of the event (considering the exclusion criteria). These parameters were estimated based on the formula proposed by Zhou, Obuchowski and $\mathrm{McClish}{ }^{(14)}$, in which the number of individuals was calculated by $n=\left(Z_{a / 2}\right)^{2}$. Se $(1-S e) / L^{2}$, with a sample number of 596 subjects. Nursing academics with a stopped course, as requested by Higher Education institutions, and Brazilian nurses working abroad, were excluded by means of self-declaration.

\section{Study protocol}

Data collection was guided by an instrument collected when the user was accepted after the presentation of the study, also via electronic form. This tool, built by the authors, consisted of questions about training, years of practice, experience with NCS and NP and application in clinical practice, among other variables that allowed better categorization of subjects and understanding their perception and knowledge regarding NCS and NP. Data were collected and categorized for their best analysis. 


\section{Analysis of results, and statistics}

A single Microsoft Excel ${ }^{\circledR}$ software spreadsheet was created to consolidate the data for the collected data. The constructed database was analyzed by the software IBM SPSS, version 20.0 for Windows and in the Statistical Package R. A descriptive analysis was made, explaining collected measures. Association, significance, Chi-square, and Mann-Whitney tests were applied.

\section{RESULTS}

The sample consisted of 596 subjects from all over the country, from 18 to 78 years of age, with a mean of 35 years, with variation of \pm 10 years and female prevalence $86.7 \%$. Of the total, 101 (16.9\%) were undergraduates in nursing and the others were nurses $(495 ; 83.1 \%)$. Of these nurses, $26.2 \%$ were specialists in nursing, followed by masters in nursing $(16.4 \%)$ and other levels.

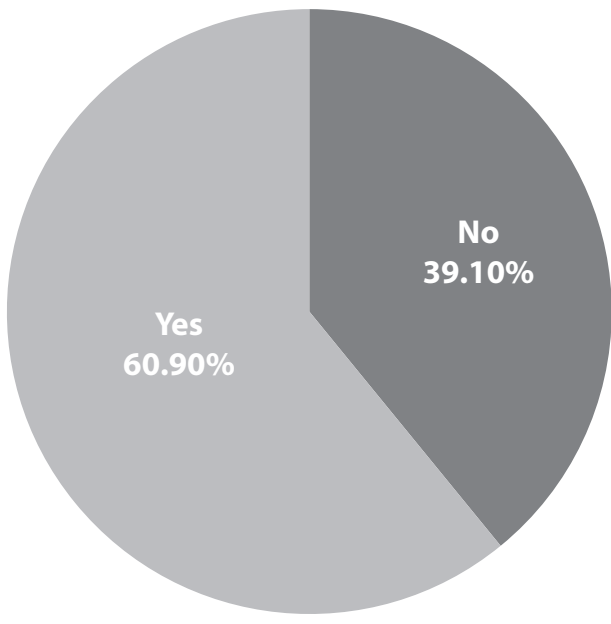

Figure 1 - Nursing Care Systematization (NCS) use in care practice, Brazil, 2018

Of all respondents, 516 (86\%) considered NCS to be very important for nursing practice. However, only a little more than half $60.9 \%(n=363)$ of nurses reported using NCS elements in their care practice, as presented in the figure 1. It was noticed through Pearson's correlation calculation that the higher the interviewee's level of training, the greater NCS use in care practice. Of the total number of patients surveyed, $50.4 \%$ stated that they used NCS principles and NP that are mandatory for nurses, and $42.7 \%$ believe that some theoretical framework is necessary to NP. $44.2 \%$ understood NP as part of NCS.

Related to the data presented in the table 1 , it is important to note that $66.8 \%$ of respondents already had some mandatory NCS training during undergraduate course. However, 33.2\% reported no, and, as expected, presented a lower level of knowledge of nursing taxonomies.

It is important to emphasize the negative association of the variable that has/does not have training on NCS during undergraduate course and knowledge of NCS. Thus, those who did not have compulsory NCS training during undergraduate course said to have a high level of knowledge on NCS. However, this may be due to an erroneous perception on the part of them, since they did not have training, but they give a high note about their knowledge of the subject, but they cannot describe nursing taxonomies or confuse them with semiology book titles and do not use NCS in care practice. These are, for the most part, nurses with more than 10 years of training and older.

Among those who completed NCS training during Postgraduate Course, $31 \%$ took additional courses on NCS ( $p<0.0001)$ and know a greater number of nursing taxonomies $(p<0.0001)$ according to table 2 . However, these are among those who give more modest scores on their knowledge of NCS $(p<0.0001)$ and are among the youngest $(p<0.0001)$. These are usually defined as having good or intermediate knowledge on NCS. However, when tested, they present good or very good levels of knowledge. Also, the degree of knowledge of those who participated in some extra training on NCS (7.2) was higher than those who did not participate $(6.3)$ ( $p<0.0001)$.

Among those who claim to use NCS in care practice (60.9\%), professionals with a higher level of training are considered and who consider clinical thinking use essential to NCS. However, among those who do not use NCS in clinical practice (39.1\%), professionals do this because it is not important, they do not know the nursing taxonomies, but they believe that they have a good command of NCS content.

Table 1 - Training, knowledge and Nursing Care Systematization (NCS) use by nurses and nursing academics, Brazil, 2018

\begin{tabular}{|c|c|c|c|}
\hline Variável & Resposta & $\mathbf{n}$ & $\%$ \\
\hline $\begin{array}{l}\text { Had/participated in some required training in Nursing Care Systematization } \\
\text { during Postgraduate Course }\end{array}$ & $\begin{array}{l}\text { Yes } \\
\text { No }\end{array}$ & $\begin{array}{l}398 \\
198\end{array}$ & $\begin{array}{l}66.8 \\
33.2\end{array}$ \\
\hline $\begin{array}{l}\text { Attended courses on Nursing Care Systematization beyond what is required in her } \\
\text { undergraduate course }\end{array}$ & $\begin{array}{l}\text { Yes } \\
\text { No }\end{array}$ & $\begin{array}{l}238 \\
358\end{array}$ & $\begin{array}{l}39.9 \\
60.1\end{array}$ \\
\hline $\begin{array}{l}\text { Had/participated in some required training in Nursing Care Systematization } \\
\text { during Postgraduate Course }\end{array}$ & $\begin{array}{l}\text { Yes } \\
\text { No } \\
\text { Had no Postgraduate Program }\end{array}$ & $\begin{array}{c}185 \\
312 \\
99\end{array}$ & $\begin{array}{l}31.0 \\
52.3 \\
16.7\end{array}$ \\
\hline Use Nursing Care Systematization in care practice & $\begin{array}{l}\text { Yes } \\
\text { No }\end{array}$ & $\begin{array}{l}363 \\
233\end{array}$ & $\begin{array}{l}60.9 \\
39.1\end{array}$ \\
\hline Level of knowledge on Nursing Care Systematization & $\begin{array}{l}\text { Very Low } \\
\text { Low } \\
\text { Intermediary } \\
\text { Good } \\
\text { Very Good }\end{array}$ & $\begin{array}{c}17 \\
33 \\
78 \\
197 \\
271\end{array}$ & $\begin{array}{r}3.0 \\
6.0 \\
13.1 \\
32.9 \\
45.0\end{array}$ \\
\hline
\end{tabular}


Table 2 - Association measure tool of variables related to perception, knowledge, and f Nursing Care Systematization (NCS) use by nursing and nursing students, Brazil, 2018

\begin{tabular}{|c|c|c|c|c|}
\hline \multirow[b]{2}{*}{ Variables } & & \multicolumn{2}{|c|}{ NCS Use in Care } & \multirow{2}{*}{$\begin{array}{c}\text { Significance } \\
\text { level }\end{array}$} \\
\hline & & $\begin{array}{l}\text { Yes } \\
\text { (\%) }\end{array}$ & $\begin{array}{l}\text { No } \\
(\%)\end{array}$ & \\
\hline \multirow[t]{6}{*}{ KNOWLEDGE } & $\begin{array}{l}\text { Training length } \\
\text { Nursing student } \\
\text { Professional - up to } 10 \text { years of training } \\
\text { Professional - over } 20 \text { years of training } \\
\text { Professional - over } 30 \text { years of training }\end{array}$ & $\begin{array}{l}61.8 \\
52.9 \\
76.9 \\
36.4\end{array}$ & $\begin{array}{l}38.2 \\
47.1 \\
23.1 \\
63.6\end{array}$ & .228 \\
\hline & $\begin{array}{l}\text { Training level } \\
\text { Graduate } \\
\text { Specialist } \\
\text { Master } \\
\text { Doctor } \\
\text { PhD }\end{array}$ & $\begin{array}{l}65.7 \\
57.7 \\
70.4 \\
77.5 \\
83.3\end{array}$ & $\begin{array}{l}34.3 \\
42.3 \\
29.6 \\
22.5 \\
16.7\end{array}$ & .004 \\
\hline & Had Nursing Care Systematization training during undergraduate course & 65.9 & 34.9 & .003 \\
\hline & Had Nursing Care Systematization training during Postgraduate Course & 67.6 & 32.4 & .033 \\
\hline & $\begin{array}{l}\text { Nursing taxonomies } \\
\text { Unknown } \\
\text { Known }\end{array}$ & $\begin{array}{l}44.1 \\
80.0\end{array}$ & $\begin{array}{l}55.9 \\
20.0\end{array}$ & .008 \\
\hline & Extra courses on Nursing Care Systematization & 68.9 & 31.1 & .001 \\
\hline \multirow[t]{2}{*}{ PERCEPTION } & $\begin{array}{l}\text { Importance of Nursing Care Systematization } \\
\text { Not important } \\
\text { Somehow important } \\
\text { Very important } \\
\text { Importance of nursing theories use along with Nursing Care Systematization } \\
\text { Importance of Clinical Thinking }\end{array}$ & $\begin{array}{c}0.0 \\
50.0 \\
65.0 \\
60.0 \\
64.6\end{array}$ & $\begin{array}{l}100 \\
50.0 \\
35.0 \\
40.0 \\
35.4\end{array}$ & $\begin{array}{l}.806 \\
.012\end{array}$ \\
\hline & $\begin{array}{l}\text { Self-perception about the degree of knowledge on Nursing Care Systematization } \\
\text { Very low } \\
\text { Low } \\
\text { Intermediary } \\
\text { Good } \\
\text { Very good }\end{array}$ & $\begin{array}{l}25.0 \\
29.0 \\
43.9 \\
31.0 \\
87.8\end{array}$ & $\begin{array}{l}75.0 \\
71.0 \\
56.1 \\
69.0 \\
12.2\end{array}$ & .000 \\
\hline
\end{tabular}

Note: NCS= Nursing Care Systematization.

When questioned about the knowledge and necessary skills that a nurse has to present to perform NCS correctly, the individuals indicated between 6 and 10 options, with a mean of $8 \pm 4.3$, standing out in order: domain on planning, domain on diagnostic inference, knowledge on clinical evaluation, knowledge on intervention, knowledge on nursing history, domain on clinical thinking, domain on NANDA-I nursing taxonomies, Nursing Interventions Classification (NIC), Nursing Outcomes Classification (NOC) and dominance on other nursing taxonomies.

As to nursing taxonomies known by users, $57.8 \%$ say they know some taxonomy, but they did not know how to remember their titles. Among those described, NANDA-I, NIC, NOC and the International Classification for Nursing Practice (ICNP) stood out. Already $11.4 \%$ ( $n=68)$ stated that they did not know any taxonomy.

It has been identified that those who describe more taxonomies have already taken extra courses on NCS, in addition to that required in undergraduate degree. And among those who do not describe taxonomies are those who claim not to use NCS in clinical practice and those who believe that mastery over clinical thinking is unnecessary. There was no statistical association between reported hours of NCS study, perception and knowledge on NCS. Apparently, the level of knowledge on NCS is more related to the attitude of seeking extra training about it, than with how many hours devoted to studying the topic.
Thus, it was observed that the majority of respondents pointed out that NP items/steps are essential to perform NCS $(p<0.001)$. It seems that nurses and nursing academics realize that having mastery of NP steps/levels is necessary to properly perform NCS, leaving aside other organizational elements of care.

Asked about the possibility of applying NP, most professionals believe that it can be applied to an individual, family, group and community. However, $12 \%(n=72)$ believe that NP can only be applied to an individual.

When questioned about what they would like to learn about NCS, and could indicate more than one option, the topics that were chosen by more than $50 \%$ of those surveyed were clinical thinking (56\%), NP (51.7\%) and nursing taxonomies (50.1\%). Other items cited referred to specific steps of NP, as well as learning about NP and its steps/levels is a necessity of the majority to better perform NCS.

Thus, the level of knowledge of the Brazilian nursing on NCS varies proportionally, according to the educational level of the individual and also for having had training on NCS in undergraduate course. Believing that NCS is irrelevant has been associated with not having or seeking extra training on the subject and believing that clinical thinking and nursing theories are of little relevance.

Thus, perception and knowledge factors influence the application of NCS in clinical practice, since the perception of relevance and the level of knowledge are directly related to NCS use/non-use. 


\section{DISCUSSION}

NCS and NP are perceived as important by the majority of nursing professionals in Brazil, but the effective application of both in the practice of nursing clinical care is still a gap to be overcome.

It is already known that among the variables present for the non-adoption of a systematized process of care are communication failures among professionals ${ }^{(8)}$, inadequate knowledge of professionals and inadequate amount of human resources ${ }^{(15)}$.

On the other hand, technologies use and the empowerment of nursing professionals during the implementation of NCS are factors that contribute to their use by professionals ${ }^{(15)}$. Thus, some authors perceive NP as a care technology that guides the sequence of clinical thinking and improves the quality of care ${ }^{(16)}$.

Researchers and civil society need to understand that NCS and NP implementation process requires cultural change ${ }^{(15)}$. It is up to professionals to understand that NCS represents not only a legal requirement, which in itself was enough to adopt it, but that it is a relevant tool that contributes to the demarcation of the role of the nurse, since it enables the professional to use his technical-scientific knowledge and care for the individual and to demonstrate their professional practice with $\mathrm{NP}^{(5)}$.

Yet, although many nurses consider that NCS is only a purely bureaucratic activity, because they claim that this time could be used for direct patient care ${ }^{(17)}$, it is necessary for them to understand the care systematization benefits well described in scientific literature.

In the present study, negative perception of NCS and NP was very much associated with the simple fact that they were not trained during undergraduate course, and the erroneous judgment of thinking that they already know enough.

Regarding the non-adoption of NCS and NP, authors have reported that many nurses perceive them as one more managerial action. However, results found do not seem to dissociate from the rest of the nursing practice around the world. A publication ${ }^{(18)}$ that sought to analyze the characteristics of the work process of nurses in different countries identified the evident similarity of the work process of the nurse in countries of different continents, the singular indissoluble nature of nursing care. However, there is much to ponder on why other countries adopt this process in their entirety. It is recommended that future studies investigate the other variables associated with the adoption of NP.

Another fact worth mentioning is knowledge on nursing taxonomies, which among the few who reported knowing, analyzing the response of all respondents, only five taxonomies were cited, even though the presence of at least 13 taxonomies and nursing classifications, to know: Center for Nursing Classification \& Clinical Effectiveness (CNC \& CN), International Classification for Nursing Practice (ICNP), Clinical Care Classification CCC, CMBD nursing, Patient Care Data Set, International Classification for Nursing Practice (ICNP), Nanda-Internacional (NANDA-I), Normalización de las Intervenciones para la Práctica de la Enfermería (NIPE), Nursing Interventions Classification (NIC), Nursing Minimum Data Set (NMDS), Nursing Outcomes Classification (NOC), OHAMA system, Perioperative Nursing Data Set (PNDS).

The fact that respondents cited less than $40 \%$ of the available taxonomies and classifications indicates the need for other works also to be known to the Brazilian community. Since these are not mentioned, and probably not yet known, they can precisely meet the needs still present in our country, but are not addressed by taxonomies and classifications already known in Brazil.

Standardized nursing language use is still a limitation to be overcome. As for this standardization of the nursing language, it should be noted that there is no taxonomy adopted worldwide except ICNP, recognized by the World Health Organization (WHO), and that each country follows a different approach ${ }^{(19)}$, since each country adopts one or more nursing taxonomies. The adoption of a standardized language contributes to the quality and safety of nursing care $^{(3)}$.

Another problem identified is the confusion that some professionals make between NCS and NP. So it is necessary to emphasize that NP is integrated as part of the whole systematization of nurses' care. However, this confusion on the part of many of respondents does not seem surprising, since even many nursing researchers use NCS and NP as synonyms ${ }^{(9)}$. More attention needs to be given to this theme, as this confusion can contribute to the weakening of scientific practices of nursing care.

Moreover, the fact that some nurses and academics perceive NCS use as optional and that can be applied only to one person is something that deserves attention, since such perception is contrary to the Nursing Council norms ${ }^{(1)}$, which can be one of the factors that determine the inadequate NCS and NP use levels.

Also, while nurses need to learn/deepen knowledge on care theories, it is also necessary that the institutions offer an environment conducive to this learning and implementation of care based on theoretical frameworks ${ }^{(12)}$.

Currently, studies point to the need for actions that strengthen the promotion of systematization within health institutions, aiming to reveal the role of the nurse as a caregiver, necessary to improve the quality of care provided to the patient ${ }^{(20)}$. It is imperative that those responsible for institutions understand and create a favorable environment for the implementation of NCS. A study that aimed to analyze the contribution of NCS to the hospital audit ${ }^{(7)}$ identified that when it is performed effectively, this in itself is comprehensiveness associated with the quality of care provided to the client, also collaborating in reducing hospitalization time and in less financial losses for health institutions. Also, the creation of institutional commissions has been reported as essential to the implementation of nursing care, training and awareness of nursing professionals regarding NCS and NP(21).

There is a growing need for educational institutions and their actors, teachers and managers involved in the teaching-learning process to intensify the positive relationship between the adoption of nursing care and the improvement of patient safety levels. Also, health institutions, which embrace nursing students, value NCS in order to favor the applicability of content learned by the nursing student ${ }^{(6)}$.

Finally, given the situation found in this national survey, it is important not only to blame care institutions and nursing professionals as responsible for the low adhesion to NCS and NP. Actions by official bodies that supervise and regulate the nursing profession are essential to the advancement of the practices of the profession and these have a high influence in the transformation of the entire caring process ${ }^{(22)}$. 
However, there is currently an effort by the Federal Nursing Council (COFEn - Conselho Federal de Enfermagem) to reach the understanding and implementation of NCS and NP, through joint actions with the Postgraduate Programs throughout the country. Thus, it is expected that researchers can commit to actions directed to NCS and to the implantation of NP with a view to improving nursing care and greater recognition of the profession ${ }^{(2)}$.

Last but not least, it is necessary to emphasize that, if the centrality of nursing is care, it is urgent that all the nursing team is involved with systematic and safe care principles. Thus, NCS fundamentals use, among the benefits already mentioned, is also a way to create and maintain a professional identity and, thus, to make NP feasible ${ }^{(23)}$.

\section{Study limitations}

The study presents limitations in the method chosen, with a focus on statistical association measures that do not allow the visualization of qualitative variables, which could explain in greater detail the cooptation of the items related to the adoption of NCS and NP by nurses and nursing students from all over Brazil.

Regional characteristics were not addressed in this study and caution is advised in the generalization of the results found here. Future studies with longitudinal observation of the behavior of the events addressed in this study are recommended.

\section{Contributions to the field of Nursing}

This study allowed to identify the variables related to the knowledge and application of NCS and NP in the country. It also verified the knowledge needs on the subject, so that future researchers, teachers and institutional representatives use the findings identified here to plan teaching-learning actions. It was possible to understand how the variables are related to each other, being able to raise in detail the profile of those who use/do not use NCS and NP. Thus, intervention actions may be better planned to reach the different subgroups and their behavioral profiles.

\section{CONCLUSION}

Nursing professionals and academics in Brazil perceive NCS as essential to the provision of clinical nursing care. However, its use and increasing knowledge on its variables and NP, which integrates care as a whole, are still barriers to be faced by professionals, educational institutions, care and by the class councils.

NCS principles use and NP steps/levels was related to the contact with this knowledge since undergraduate course and to the attitude of seeking extra training on the subject. Devaluation of care theories and the clinical thinking process was related to professionals who did not have training on NCS and NP, being remarkable to emphasize the need for strategies to reach these professionals, with a view to making nursing care safer.

This study points out that knowledge (acknowledgment) of clinical thinking is essential for a positive attitude toward NCS. Training on this field is recommended before even working on aspects of NCS.

However, using NCS principles is an obligation not only of a legal but also ethical. It is no longer possible to postpone the fulfillment of the wishes of a population that desires and deserves quality nursing care due to dissonant perceptions of what is predicted in the academic literature. Thus, systematizing all care and, consequently, making NP feasible, is a goal of modern nursing.

\section{REFERENCES}

1. Conselho Federal de Enfermagem (COFEN). Resolução COFEN n 358/2009. Dispõe sobre a Sistematização da Assistência de Enfermagem e a implementação do Processo de Enfermagem em ambientes, públicos ou privados, em que ocorre o cuidado profissional de Enfermagem, e dá outras providências [Internet]. Brasília: COFEN; 2009. [cited 2018 Jul 15]. Available from: http://www.cofen.gov.br/resoluo-cofen-3582009_4384.html

2. Silva MCN. Sistematização da assistência de Enfermagem: desafio para a prática profissional. Enferm Foco. 2017;8(3). doi: 10.21675/2357707X.2017.v8.n3.1534

3. Gutierres LS, Santos JLG, Peiter CC, Menegon FHA, Sebold LF, Erdmann AL. Good practices for patient safety in the operating room: nurses' recommendations. Rev Bras Enferm [Internet]. 2018;71(Suppl 6):2775-82. [Thematic Issue: Good practices in the care process as the centrality of the Nursing]. doi: 10.1590/0034-7167-2018-0449

4. Riegel F, Oliveira Jr NJ. Nursing process: implications for the safety of surgical patients. Cogitare Enferm. 2017;22(4):1-5. doi: 10.5380/ ce.v22i1.45577

5. Bandin M, Toledo VP, Garcia APRF. Contribution of transference to the psychiatric nursing process. Rev Bras Enferm [Internet]. 2018;71(Suppl 5):2161-8. [Thematic Issue: Mental Health]. doi: http://dx.doi.org/10.1590/0034-7167-2016-0640.

6. Pereira GN, Abreu RNDC, Bonfim IM, Rodrigues AMU, Monteiro LB, Sobrinho JM. Relação entre sistematização da assistência de enfermagem e segurança do paciente. Enferm Foco. 2017;8 (2):21-5. doi: 10.21675/2357-707X.2017.v8.n2.985

7. Nomura ATG, Silva MB, Almeida MA. Quality of nursing documentation before and after the Hospital Accreditation in a university hospital. Rev Latino-Am Enfermagem. 2016;24:e2813. doi: 10.1590/1518-8345.0686.2813

8. Gengo e Silva RC, Diogo RCS, Cruz DALM, Ortiz D, Ortiz D, Peres HHC et al. Linkages of nursing diagnoses, outcomes, and interventions performed by nurses caring for medical and surgical patients using a decision support system. Int J Nurs Knowl. 2018;29(4):269-75. doi: 10.1111/2047-3095.12185

9. Fuly PSC, Leite JL, Lima SBS. Correntes de pensamento nacionais sobre sistematização da assistência de enfermagem. Rev Bras Enferm. 2008;61(6):883-7. doi: 10.1590/S0034-71672008000600015 
10. Olatubi MI, Oyediran OO, Faremi FA, Salau OR. Knowledge, perception, and utilization of Standardized Nursing Language (SNL) (NNN) among nurses in three selected hospitals in Ondo State, Nigeria. Int J Nurs Knowl. 2019;30(1):43-8. doi: https://doi. org/10.1111/2047-3095.12197

11. Gomes RMGM, Teixeira LSTS, Santos MCQ, Sales ZN, Linhares EF, Santos KA. Sistematização da assistência de enfermagem: revisitando a literatura brasileira. Id On Line Rev Mult Psic. 2018;12(40):995-1012. doi: 10.14295/idonline.v12i40.1167

12. Rosa R, Costa R, Souza AIJ, Lima MM, Schneider DG, Santos EKA. Reflections of nurses in search of a theoretical framework for maternity care. Rev Bras Enferm [Internet]. 2018;71(Suppl 3):1351-7. doi: 10.1590/0034-7167-2016-0525

13. Ribeiro OMPL, Martins MMFPS, Tronchin DMR, Forte ECN. Implementation of the nursing process in Portuguese hospitals. Rev Gaúcha Enferm. 2018;39:e2017-0174. doi: 10.1590/1983-1447.2018.2017-0174

14. Zhou XH, Obuchowski NA, McClish DK. Comparing the accuracy of two diagnostic tests. In: Zhou XH, Obuchowski NA, McClish DK, editors. Statistical Methods in Diagnostic Medicine. New York: John Wiley \& Sons; 2011. p. 165-192. doi: 10.1002/9780470906514.ch5

15. Kang Y, Hwang WJ, Choi J. A concept analysis of traditional Korean (Hanbang) nursing. Int J Nurs Knowl. 2019;30(1):4-11. doi: 10.1111/2047-3095.12195

16. Dal Sasso GTM, Barra DCC, Paese F, Almeida SRW, Rios GC, Marinho MM, et al. Computerized nursing process: methodology to establish associations between clinical assessment, diagnosis, interventions, and outcomes. Rev Esc Enferm USP. 2013;47(1):238-45. doi: 10.1590/ S0080-62342013000100031

17. Ribeiro JC, Ruoff AB, Baptista CLBM. Informatização da Sistematização da Assistência de Enfermagem: avanços na gestão do cuidado. J Health Inform [Internet]. 2014. [cited 2018 jul. 15]; 6(3):75-80. Available from: http://www.jhi-sbis.saude.ws/ojs-jhi/index.php/jhi-sbis/ article/view/296/199

18. Leal JAL, Melo CMM. The nurses' work process in different countries: an integrative review. Rev Bras Enferm [Internet]. 2018;71(2):413-23. doi: http://dx.doi.org/10.1590/0034-7167-2016-0468

19. Safdari R, Azadmanjir Z. Solutions and strategies for nursing informatics development. Int J Nurs Health Sci [Internet]. 2014. [cited 2018 Jul 15];1(1):4-12. Available from: http://www.openscienceonline.com/journal/archive2?journalld=719\&paperld=375

20. Xavier LF, Silva SBM, Oliveira OD, Nazario YCOS, Morais Jr SLA. Sistematização da assistência de enfermagem: o conhecimento de enfermeiros do município de Ji-Paraná, Rondônia, Brasil. Nursing (São Paulo) [Internet]. 2018[cited 2018 Jul 15];21(239):2110-3. Available from: http://www.revistanursing.com.br/revistas/239-Abril2018/sistematizacao_assistencia_de_enfermagem.pdf

21. Alencar IGM, Nunes VS, Alves AS, Lima SLR, Melo GKM, Santos MAF. Implementation and implantation of the systematization of nursing assistance. Rev Enferm UFPE. 2018;12(4):1174-8. doi: 10.5205/1981-8963-v12i4a231030p1174-1178-2018

22. Sundean LJ, Polifroni EC, Libal K, McGrath JM. The rationale for nurses on boards in the voices of nurses who serve. Nurs Outlook. 2018.;66(3):222-32. doi: 10.1016/j.outlook.2017.11.005

23. Gutiérrez MGR, Morais SCRV. Systematization of nursing care and the formation of professional identity. Rev Bras Enferm [Internet]. 2017;70(2):436-41. doi: 10.1590/0034-7167-2016-0515 